\title{
Higher Education Administration And Globalization In The 21st Century In India
}

Taghi Jabbarifar, University of Yazd, Iran

\begin{abstract}
This article deals with the changing scenario and management responsibilities of higher education in the $21^{\text {st }}$ century in India. Of course, for those looking for challenges of management in higher education as a field, the future is not going to be a disappointment. Maybe by the end of the first decade of the $21^{\text {st }}$ century management of higher education worldwide would have changed beyond recognition. Every administrator is required to behave like a shrewd politician. The world has been changing very fast. The pace of liberalization, privatization and globalization $(L P G)$ is remarkable and has tremendously influenced various dimensions of management of higher education. The long-term consideration in the educational sector requires a clear statement of the direction in which a society wishes to move. Thus it is necessary to visualize the type of society India would like to have in the $21^{\text {st }}$ century and beyond
\end{abstract}

Keywords: Higher Education, Administration, Globalization, College, University, India

\section{INTRODUCTION TO HIGHER EDUCATION}

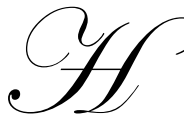

igher education is at crossroads and is passing through exciting times. Increasing competition, widespread educational activities, global character and enhancement of technology are some of the significant factors creating a great impact on higher education. While it is in a phase of turbulent years of transition, it still provides highly talented human resources for economic development, brain power enhancement and research in several areas. Academic institutions all over the world are contributing significantly to societal development and refinement of perception. These institutions are working as centers of learning, training and manpower development. Their role has been a vital source of industrial development and creation of wealth. Planners, managers, legal authorities, scientists and researchers receive guidance from these institutions. The strategic planning and management of these institutions have to cope with challenges, such as the urge for excellence, up-gradation of skills, accessibility vis-a-vis mass education, IT revolution, resource crunch, teachers' empowerment, student-support services, government control, liaison with the university, trade unionism and so on. The administrators of collegiate institutions have to take these challenges into account while planning their strategies.

\section{ROLE OF COLLEGE ADMINISTRATION}

A college is the fundamental element of higher education in India and is supposed to produce quality graduates, whereas the University is primarily committed to research and generation of super advanced new knowledge. Most scholars agree that knowledge is power. The younger generation of the $21^{\text {st }}$ century believes that applied knowledge is power. Whatever we think about knowledge and new knowledge we must appreciate their point of view. Otherwise we will stay so far behind that we may never be able to catch up with them. In the light of the above challenges, it is very pertinent to run any academic institution in such a manner that the objectives of creating good citizens and undertaking educational activities relevant to the times are fulfilled. The college administration in India, therefore, is required to be dynamic in its approach. It has to perform both the roles of academic development on the one hand and smooth functioning on the other. Good administration and sound academic performance are mutually dependent and inseparable. Therefore, the colleges have to manage the affairs 

performance. Many collegiate institutions have imbalance in terms of their administration and academic pursuits. Some organizations have good administrative capacity but the academic pursuits are put in the background. There is no scarcity of resources but less emphasis is laid on academics. In some cases, infrastructure is attractive but the results are poor. It is always necessary to establish balance with optimum administration and consistency in academic pursuits.

\section{LINKAGE OF COLLEGES WITH THE UNIVERSITY}

The college administration in Indian Higher Education in the $21^{\text {st }}$ century has links with universities and the government. Majority of colleges are affiliated to universities for academic guidance and certification of their standards. The state universities and statutes of the respective universities govern colleges. The service conditions of college teachers are governed by the University rules and regulations. The state government controls the financial aspect of college management. Pay scales, grant-in-aid, recruitment policy and other such components constitute the regulatory measures of the Government of India. Therefore, for smooth functioning of the college, the liaison with the university and the government is very important. The colleges run by private management have to develop relations with the authorities of these institutions. The management representatives on the local managing committees and governing bodies of the institutions have a vital role to play in the management of the colleges. As a result, the principal of a college has to manage the activities in the framework of rules and regulations of the university, government and management. The University Grants Commission (UGC) is also an important regulatory body for colleges, particularly, for developmental assistance and funding for several schemes.

The National Assessment and Accreditation Council (NAAC) has also, in recent times, created a quality consciousness among teachers and administrators of colleges. Thus, the administration of colleges has many factors to be considered in a balanced manner with an optimum consistency. It has the ultimate aim of facilitating education for students' development and quality maintenance.

\section{PARTICIPATION IN COLLEGE ADMINISTRATION}

College administration has three pillars in the Indian context-teachers, administrative staff and management of institutions. Higher Education has to enhance human capability through empowerment that knowledge gives. Here, not only do the teachers have to share the initiative but also the functioning of management has to be participative. The participative approach will make teachers responsive and accountable to the students. It will also ensure good performance through in-built appraisal methods. This will give them an opportunity to participate in the process of management and enjoy the autonomy of thought and action in the process of teaching and evaluation of their students. College management must be able to operate the mechanisms of having regular meetings with lecturers, office staff and student representatives. This would motivate everyone to strive for better performance. As advised by Freud (1991), "In major decisions you must consult not only your head but also your heart."

\section{FACTORS OF GOOD COLLEGE MANAGEMENT}

Good college management and administration depend on a number of factors. They are interrelated and it becomes a primary duty of the principal of a college to correlate them and establish a working balance. The following are some of them.

\section{Management Support}

A continuous and healthy relation with management representatives is a key factor in day-to-day functioning of the college. It is the duty of the management to protect the institutions from the external encroachments and interference of unnecessary elements. At the same time it should have the first priority to select an appropriate person to lead the institution and then give him or her full freedom and flexibility to work. Some institutions follow this religiously and enjoy the results of good performance. The responsibility and answerability should be in-built in the system of college management. 
Colleges are a focal point of national and international integration and have to be viewed and as such. Upgrading of skills of the students is the need of the hour. This is critical for development and helps in meeting the requirements of working patterns. The role of college administration is, therefore, significant in correlating academic inputs to satisfy the competitive urge for excellence in the world.

\section{Working As A Team}

Every activity of the college is a team activity. At any college, teamwork and sharing of ideas are of prime importance. The head of the institution has to bear in mind that delegation of authority and division of work always go hand in hand. Faith in colleagues is a key factor. There can be a formal hierarchy in internal management and at the same time a lot of work can be carried out on the basis of informal relations. Curricular and extra-curricular activities in the college have to be shared by all. Freedom to the colleagues and flexibility in working are the main dimensions of this. It is the responsibility of the head of the institution to ensure that decision-making and implementation of decisions are always collectively done. Coming together is a beginning. Thinking together is a process; and working together is success.

\section{Responsive Administrative Staff}

Administrative staff of an academic institution in India is a core part of its functioning. Office administration, correspondence, accounting, record keeping, maintenance of infrastructure etc. are the continuing activities of the administration. Participation of administrative staff in administration should be encouraged and the working of the college office made efficient in every respect. An efficient head fails to perform his or her duties if the administrative staffs are not responsive and dynamic in carrying out various programmes.

\section{Financial Transparency}

The financial aspect of administration should be totally transparent and governed by ethics and moral values. As a college is a public institution, every care has to be taken to maintain and develop faith of stakeholders and people in general.

\section{Learner- Centered Approach}

The student is the main stakeholder in the process of education. Integrity of teachers is counted in terms of their sincerity in performing the duty of imparting knowledge. It is a duty of the administration to see that this process of learning and training gets the prime importance in the functioning of the college. Reputation of an institution is always decided on the basis of the quality of its output. The learner centered approach has to be reflected in the curriculum, personality development programmes, guidance and regular class teaching. The social image of the institution is always built up on this foundation.

\section{Innovativeness And Educational Experiments}

In view of the emerging trends in education, it is the duty of the college administration to explore new avenues and adopt innovative approaches. Research activities, vocationalisation, add-on-career oriented courses, IT related innovations; experiments in the teaching-learning process and development of quality assurance cells are some of the notable features. They will certainly improve the performance of the institutions.

\section{Students Placement Center}

The college administrators are responsible for placement of their students. For that they need the best quality of education. 
College administration is a complex task. It has many angles to be considered. The challenges in the modern times have created a sense of competition and quality consciousness among constituents of college administration. It has some constraints and inherent limitations, which cannot be ignored in the administration process. Liberalization, privatization and globalization of education have become the buzzwords but at the same time the complexities are also increasing. The government is almost withdrawing itself from providing financial assistance. Private unaided-managements have developed a sense of commercialization of administration. The number of students in basic sciences, humanities and languages is declining very fast. The private-unaided institutions have monopolized careers in technology and medicine. The resource crunch has become more severe due to the recent policies of the government. It is only through proper planning and observance of austerity measures that the colleges can now be run, particularly when the philanthropic instinct too has gradually disappeared and higher education has gone to the commercial entrepreneurs who have started promoting it for profit. Industry interface, resource sharing, pooled teaching, classes in the evening, autonomous courses and such other sources can be beneficial to a large extent.

\section{RESPONSIBILITIES OF COLLEGE ADMINISTRATION}

It is clear that the principal of a college has a definite role in planning and college activities. S/he is the catalyst in pursuing the ideals for which the college stands. Of course, it cannot be done without the support of teaching and office staff and management of the institution (Trustees). In the context of the above listed challenges, the principal has to develop his/her style of functioning in such a manner that the administration becomes a collective and co-operative activity. S/he has to combine vision with routine work, evolve interactive approach and sharing of ideas in the spirit of teamwork. The call for social responsibility and converting a period of transition into an era of quality improvement can be responded to successfully by the college administration with collective vision and a zealous attitude It can produce a generation of youth with confidence to face the challenges of the times.

In the past, educational processes were not confronted with the kind of challenges, which have to be faced today. Presently, technologies are changing much more radically and rapidly than ever before. What are the college administrators supposed to do? They must go along with the changes. The technological changes are resulting in changes not only in tools, the infrastructure and the profiles of work-related activities but also in organizational structures, demographic profiles and even the concepts associated with national identity and sovereignty.

A college administrator must be a good planner, for nobody knows for sure what the world of the year 2020 and further will look like. But judging from the rate of changes during the last decade, it seems reasonable to state that the 20s and 30s of the 21 st century will be different from the contemporary world, by an order of magnitude unprecedented in history. In spite of this forbidding prospect, the educational planners and administrators of colleges today have to start thinking of the manner in which the people living in this sub-continent will be able to respond to the challenges most entrants into the portals of colleges and universities will have to face.

\section{GLOBALIZATION AND ADMINISTRATION}

Waters, an authority on globalization, believes that although the word global is over 400 years old, the common usage of such words as 'globalization', 'globalize' and 'globalizing' did not begin until about 1960. Webster became the first major dictionary to offer definitions of "globalism and globalization" (Behar, 2005).

Nobel Laureate Joseph Stiglitz defines globalization as removal of barriers to free trade and the closer integration of national economies (Stiglitz, 2002, as quoted in Behar, 2005).

Globalization is today a new trend—not just in economic, commercial and technological fields, but also in education. In the meantime the supreme court of India made judicial history when the court constituted a five-Judge Bench to interpret the judgment of an 11-Judge Bench on private higher education, its judgment delivered on October 31, 2000 that higher education be privatized. Now the higher education administrations legally have been permitted to establish and develop private institutions in India. The responsibilities of administration are: 
- $\quad$ All the staff should be informed clearly about globalization and privatization.

- $\quad$ The objectives of globalization should be made clear.

- Not more than $30 \%$ institutions should be private institutions and there may be $70 \%$ government institutions.

- $\quad$ The government has the responsibilities to control the activities of private institutions.

- $\quad$ Students should have the right to select what they need and what is good for them.

\section{SUGGESTIONS}

Higher education administration in the $21^{\text {st }}$ Century in India must train people not only for the present but also for the future. Given the great impact of liberalization, privatization and globalization of knowledge, what will happen to the great variety of socio-cultural norms and organizational structures existing in India today? Will the people living in different micro environments, with their own uniquely distinctive life styles, be able to retain their individuality and protect their culture and values, or will people every where in India, become the clones of people in the US, Japan, Germany or some other developed country? The opinion of Tata becomes relevant on this issue: "To be a leader you have got to lead human beings with affection." (Batra, 1992). We need to remember theses words for the development of education field.

Therefore, it is suggested that:

- The challenge of the $21^{\text {st }}$ century is a challenge to survive as institutions of quality or excellence.

- Universities and colleges will have to build credibility for themselves and make their operations simple, efficient and meaningful.

- Universities and colleges will be forced to accept liberalization, privatization and globalization, so that students as clients or customers would choose what they want on the basis of their tastes and needs.

- Improving the efficiency of the university and college administration system is more urgent than ever before. One obvious way of doing this will be to impart professional raining to those already engaged in educational administration.

- Availability of equipment as well as teaching and research facilities of the highest order will become a major concern. New procedures need to be adopted for procurement and maximum returns should be ensured before investment. If the institutions see the fundamental need to go deep with a view to adopting new approaches and processes to bring about changes, they will be equipped to meet the challenges of the $21^{\text {st }}$ century.

\section{AUTHOR INFORMATION}

\section{Name. Taghi}

Family name. Jabbarifar

Date and place of birth: 1/10/1950 Isfahan, Iran.

Education:

- $\quad$ K-12 Isfahan 1957-1969

- $\quad$ Soldiers teacher 1970- 1973

- $\quad$ Learning English: Swan School of England and Oxford College of Education. 1973-1975

- $\quad$ AA Delta College University Center Bay City Michigan.1978-1980

- $\quad$ BS Central Michigan University Mt Pleasent Michigan 1980-1984

- $\quad$ University of Denver 1985-1987.Subject Educational administration.

- PhD University of Pune, India. 2004-2007 Educational Administration, thesis Higher education administration (Management and planning).

Work Experience:

- $\quad$ Oscoda Public Schools 1982-1983 teaching and coaching. 
- $\quad$ Days Denver Colorado Teaching and coaching. 1984-1986

- University of Yazd, Iran. Department of Education. Staff member, teaching and working in student teacher training center, 1988 to present time.

\section{REFERENCES}

1. $\quad$ Batra, P. (1992). A collection of management thoughts. New Delhi: Think Inc.

2. Waters, Michael \& (Stiglitz, Joseph, 2002 (as quoted); In Behar, S.C. (2005). Globalization- education, perceptions and processes. Pune: Indian Institute of Education

\section{NOTES}

